\title{
THE PRESERVATION OF HUMAN BLOOD IN GLASS AND PLASTIC CONTAINERS: AN IN VITRO EVALUATION
}

JeAN-MARIE LOISELLE, M.D., PH.D., ${ }^{1}$ and Feríandó Hudșon, M.D., F.R.C.P.(c) ${ }^{2}$

BECAUSE OF conflicting reports in the literature concerning the effects of plastic containers on red blood cells $(1-7)$, there has been and still is some hesitation in substituting plastic for glass containers for blood storage. As evidence of this uncertainty, there is the known fact that many of the blood banks are still using both types of container indiscriminately. In order to throw light upon the problem, our present investigation was undertaken with the practical objective of finding out which is less detrimental to red blood cells. However, it must be

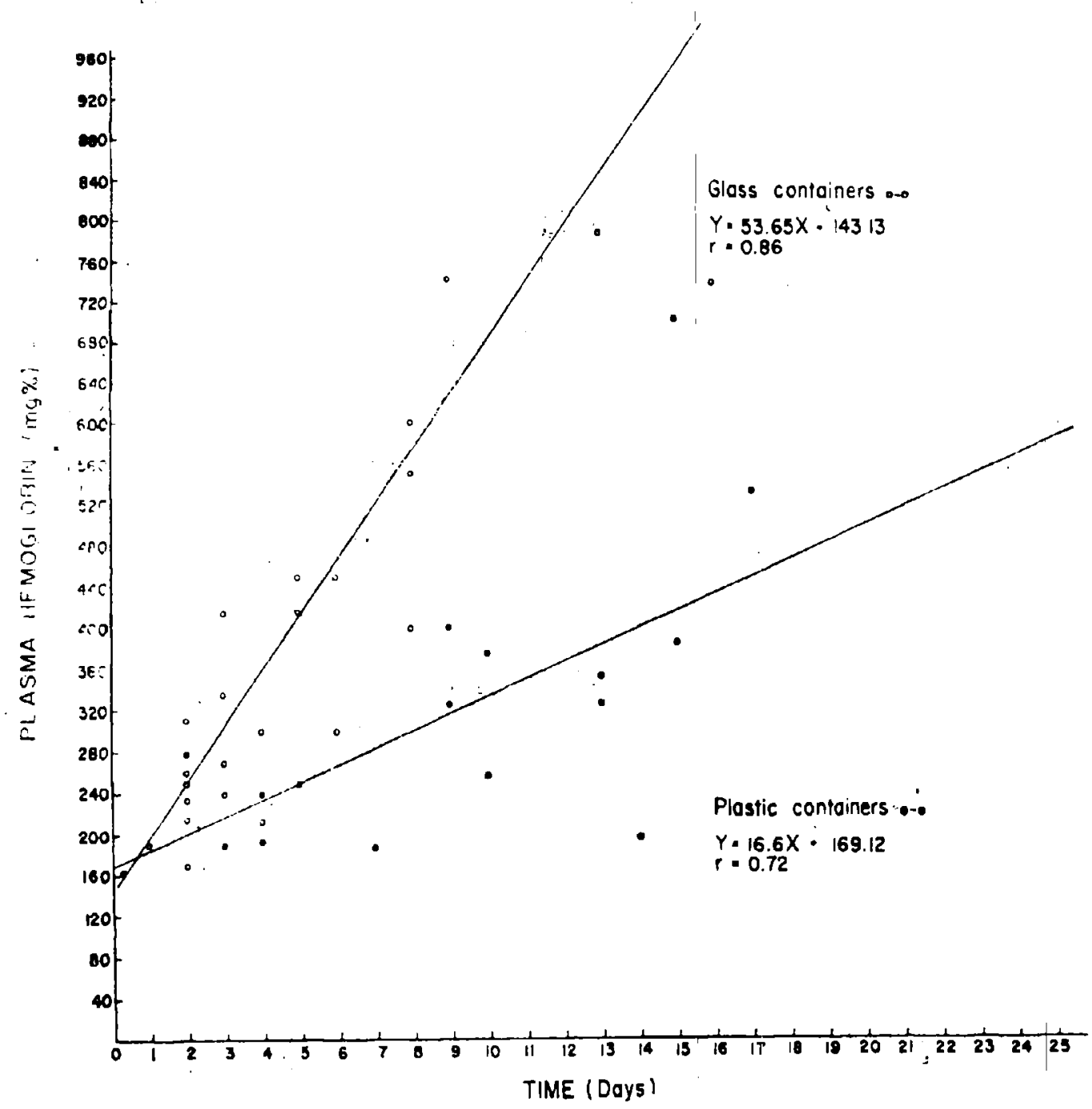

Figure 1

${ }^{1}$ Biochemist, 'Hôtel-Dieu Hospital, Quebec City, P.Q.

${ }^{2}$ Chief Anaesthetist, Hôtel-Dieu Hospital, Quebec City, P.Q. 
emphasized that this study was intended to compare only the effectiveness of glass and plastic containers in the preservation of blood, not their individual differences.

\section{EXPERIMENTS}

During a one-month period, blood was withdrawn from one group of 31 human donors and stored in glass containers ${ }^{3}$ and from another group of 48 and storęd into plastic containers. ${ }^{4}$ Donors were male and female healthy persons. The blood specimens were then kept in a refrigerator at a temperature ranging from 6 to $8^{\circ} \mathrm{C}$. and taken out only at the end of the collection period for the sampling procedure.

At the time of sampling, a $10 \mathrm{ml}$. blood sample was drawn from each container by means of a syringe and a 16-gauge needle, then gently poured into a Lusteroid type of centrifuge tobe. The centrifugation was carried on in the cold $\left(0-4^{\circ} \mathrm{C}\right.$.) at 2,500 r.p.m. for'fifteen minutes. The plasma was decanted and kept for haemoglobin content determination. The plasma haemoglobin content was estimated according to the method recommended by Storck and Ardry (8).

\section{REsults}

The haemoglobin content of each plasma sample was expressed in milligrams per 100 millilitres and plotted against time of storage (Fig. 1). Circles represent the results obtained with glass (vacuum bottle) containers and dots the results obtained with plastic containers. In both sets of results, the curve of best fit was found and the equation of their respective regression curves. indicated thereby.

TABLE I

\begin{tabular}{|c|c|c|c|c|}
\hline & \multirow{2}{*}{$\begin{array}{l}\text { Correlation coefficient } \\
\qquad \begin{array}{c}r \pm \sigma r \\
\end{array}\end{array}$} & \multicolumn{2}{|c|}{ Equation of regression curves } & \multirow{2}{*}{$\begin{array}{c}\text { Standard croor } \\
\text { of the sample in } \\
\text { absolute value } \\
\quad S y \dagger\end{array}$} \\
\hline & & $Y=m X+k$ & $\pm \sigma m^{*}$ & \\
\hline Glass contàiners & $8.86 \pm 0.075$ & $Y=53.65 X+143.13$ & $\begin{array}{r}4.59(1) \\
-8.74(2)\end{array}$ & 125.97 \\
\hline Plastic containers & $0.72 \pm 0.123$ & $Y=16.6 X+169.12$ & 1 & 106.26 \\
\hline
\end{tabular}

$\sigma m=$ Standard error of angular coefficient. The $t$ value between $\sigma m_{1}$ and $\sigma_{2}$ is 6.9 .

tThis standard error of the sample is given in the same unit as $Y$.

As indicated in Table I, the correlation coefficient $(r \pm$ or) of the two series of results was highly significant. Actually, an $r$ value equal to $0.86 \pm 0.075$ was calculated from results obtained with glass containers, whereas an $r$ value of $0.72 \pm 0.123$ was calculated from results obtained with plastic containèrs.

The $t$ value between the standard error of each angular coefficient ${ }^{\tau} m_{1}$ and $\mathrm{a} m_{2}$ ), derived from the equations of regression curves, was equal to 6.9. The difference therefore is highly significant.

3Transfuso-vac., F.83, Baxter Laboratories of Canada, Acton, Ont.

4Pliapak A.D.C. Solution, Abbott Laboratories, Montreal, P.Q. 


\section{Discussion and Concrusion}

It is noteworthy that, in spite of our scattered results, in both cases the $r$ values are very good. The correlation between the factors "time of storage" and "haemolysis of stored blood cells" is real and directly proportional. According to Strumia, Colwell, and Dugan (9), this red blood cell damage might be attributable to toxic substances leached from the material, glass or plastic, of which the containers arei made.

Of more interest is the $t$ value. It testifies strongly to the significance of our results and indicates that the rate of haemolysis is far more rapid when blood is stored in glass containers than in plastic containers.

\section{SUMMARY}

Ylasma naemoglobin content was determined in samples of blood withdrawn from glass and plastic containers where it had been stored for different periods of time. Our results indicate that the rate of haemolysis is far more rapid when the blood is stored in glass than in plastic containers.

\section{RÉSUMÉ}

L hémoglobine plasmatique a été mesuré dans des échantillons de sang d'âge différent venant de récipients en verre et en plastique.

Nos. résultats indiquent que la vitesse d'hémolyse sanguine est beaucoup plus rapide dans le'sang conservé dans des récipients en verre que dans celui conservé dans des récipients en plastique.

\section{REFERETNCES}

1. SACK, T., Grason, J. G., \& BuckLEy, E. S. The preservation of whole ACD blood Collected, Stored and Transfused in Plastic Equipment. Surg., Gynec., \& Obst. 95: 113 (1952).

2. Muether, R. O., Sommer, A. J., \& Koster, B. Studies on Blood Stored in Plastic Bags. Am. J. Clin. Path. 23: 818 (1953).

3. Knutson, K. P. Plastic Blood Containers. Am. J. Clin. Path. 23: 813 (1953).

4. Wali, R. L.; Shinowara, G.; Bouroncte, B.; Deleeww, N. K. M., \& Doan, C. At An Evaluation of the Preservation of Human Blood Stored in Experimental Plastic Containers: In vitro Studies. J. Lab. \& Clin. Med. 42: 665 (1953).

5. Wall, R. L., Bucruey, N. M., \& DonN, C. A. An|Evaluation of the Preservation of Human Blood Stored in Experimental Plastic Containers: In ritro Studies: T. Lab. \& Clin. Med. 42: 674 (1953).

6. Sтrumis, M. M. The Preservation of Blood for Transfusion. Blood 9: 1105 (1954).

7. Strumis, M. Ml, Colwell, L. S., \& Ellensereer, $X$. The Preservation of Blood for Transfusion: I; The Effect of Plastic Containers on Red Cells. J. Lab. \& Clin. Med. 46: 225 (1955).

8. Storcr, J., \& Ardny, R. Colorimetric Micro Determination of Hemoglobin in Biological Media. Ann. Biol. Clin. 9: 197 (1951).

9. Strumar, M. M., Colwerl, L. S., \& Dugan, Ann. The Preservation of Blood for Tranisfusion: III, Mechanism of Action of Containers on Red Blood Cells. J. Lab. \& Clin. Med. 53: 108 (1959). 